\title{
Corporate ownership and control contestability in emerging markets: The case of Colombia
}

\author{
Luis H. Gutiérrez ${ }^{\mathrm{a}}$, Carlos Pombo ${ }^{\mathrm{b}, *}$ \\ a Department of Economics, Universidad del Rosario, Bogotá, Colombia \\ b School of Management, Universidad de los Andes, Bogotá, Colombia
}

Received 3 May 2007; received in revised form 6 December 2007; accepted 16 January 2008

\begin{abstract}
This study examines the structure of voting control and blockholders' contestability for a sample of 233 non-financial listed firms in Colombia during 1996-2004. Corporate control is characterized by high ownership concentration and blockholder power, which implies low separation ratios between cash flow rights and voting rights. On average the separation ratios for the largest voting block is 0.95 , while that for the fourth largest shareholder is 0.75 . Corporate control is privately biased when there is direct monitoring of firm management by controlling owners. Regression results show that a more equal distribution of equity among large blockholders has a positive effect on firm value. Contestability matters most when firm shares are liquid and actively traded on the stock market. This finding is reinforced when the probability that the largest block can form a winning coalition decreases and performance variables, such as market to sales ratio and return on equity, are included in the estimating equations as substitutes for firm value. In addition, our estimations provide evidence that diversion of rents (tunneling) is limited by blockholders' contestability. (C) 2008 Elsevier Inc. All rights reserved.
\end{abstract}

JEL classification: G32; L14; L22

Keywords: Corporate control; Multiple blockholders; Corporate governance; Firm value; Colombian corporations

\section{Introduction}

Recent empirical studies of corporate governance in developing and emerging economies have addressed the relationship between ownership and control rights, with firm performance measured by either valuation or accounting measures. For a cross-sectional sample of 23 countries, La Porta,

\footnotetext{
* Corresponding author. Tel.: +571 3394949x3976; fax: +571 3324551.

E-mail addresses: lgutierr@urosario.edu.co (L.H. Gutiérrez), cpombo@uniandes.edu.co (C. Pombo).
} 
Lopez-de-Silanes, and Shleifer (1999) found that ownership was highly concentrated around the world. Using a sample of 2980 companies in nine countries in East Asia, Claessens, Djankov, and Lang (2000) corroborated the results of La Porta et al., and the studies in Barca and Becht (2001) for the most representative European countries also found very high levels of direct ownership concentration. Further, Holderness (2006) presents evidence that, contrary to widespread belief (and studies), U.S. ownership concentration is similar to that elsewhere.

Gutiérrez, Pombo, and Taborda (2008) carried out the first calculations of direct ownership and control rights for an average of 140 non-financial listed corporations in Colombia during 1996-2002. Their results show that the stakes of the four largest shareholders in listed corporations increased from an average of $60 \%$ in $1996-1999$ to $65.3 \%$ in $2000-2002$. The mean of the ratio of cash flow rights to voting rights for the top four voting blocks was 0.77 , relatively high. On average, Colombian levels of ownership concentration and separation of control from ownership resemble those found in continental Europe and East Asia.

Findings about the effect of ownership and control rights on a firm's performance have been mixed, but it has frequently been found that a large owner may have incentive to monitor management, what is called the incentive effect. It has also been shown theoretically that a negative effect called tunneling may take place if large shareholders extract private rents to the detriment of the minority shareholders. Researchers have approached this second effect empirically, using some wedge measure of the difference between control rights and ownership rights or its ratio. ${ }^{1}$ Gutiérrez and Pombo (2007) tested both effects for Colombian listed companies. Their findings give strong support to the incentive effect when taking Tobin's $Q$ as the dependent variable. The entrenchment or tunneling effect was found when using accounting variables ROE and ROA as the dependent variables.

Lately, theoretical development and empirical studies in corporate governance have addressed settings with more than one large blockholder, which allows some level of contestability to emerge on the basis of coalitions that can be formed among the large blockholders. ${ }^{2}$ This type of contestability may limit the power of the largest blockholder to divert funds (tunneling) for his own benefit. To assess the relationship between a firm's performance and control contestability exerted by large blockholders, excluding the largest one, in Colombian listed corporations, we use data for 233 non-financial listed firms with at least one large blockholder having $10 \%$ or more of direct ownership or cash flow rights. Afterward, we measure some proxies for control contestability, which allowed us to test the hypothesis already verified by Maury and Pajuste (2005) on how control contestability relates to a firm's performance. We then try to go further in revealing the nature of corporate governance in Colombian listed companies. Our main hypothesis is corroborated: as control contestability increases, in the sense that either ownership or control rights among the four largest blockholders tend to be better distributed, opportunities to carry out expropriation or extract private rents decrease, which leads to better firm performance. This finding is dependent on the degree of liquidity of the share of listed companies, which may help explain the positive and strong finding in Gutiérrez and Pombo (2007) of a link between affiliation of firms to business groups and firm value. Lastly, our findings show that regardless of the level of stock market development, investor protection through control contestability is a key corporate governance mechanism that enhances good firm performance.

\footnotetext{
1 See Claessens et al. (2002, 2006) among others.

2 For more details, see Pagano and Roell (1998), Bennedsen and Wolfenzon (2000), Bloch and Hege (2001), and Gomes and Novaes (2006).
} 
The recent studies collected by Chong and Lopez-de-Silanes for Latin America (2007) on investor protection and corporate governance, provide evidence of the existence of multiple large shareholders across Latin American corporations. They also present measures of separation between cash flow rights and voting rights due to business group affiliation and the issuance of non-voting shares, in accordance with the above-mentioned cross-country studies done for East Asian and European markets. This study deep the analysis about the role of multiple large shareholders in listed companies by modeling their strategic interactions that might involve either contestability vis-à-vis the largest blockholder or the possibility of forming a sustainable coalition to get firm control, in a emerging market with poor legal protection in the sense of La Porta, Lopez-de-Silanes, Shleifer, and Vishny (1998). ${ }^{3}$

Empirical studies close to ours are the one by Gutiérrez and Tribó (2004) for a large sample of non-public Spanish corporations and the one by Maury and Pajuste (2005) for a sample of listed Finnish firms. Gutiérrez and Tribó found that the contestability proxy is positively related to performance, observing that "the similarity in the stakes of the first and second shareholders is likely to enhance both the bargaining power and the monitoring incentives of the second shareholder" (2004, p. 17). Maury and Pajuste (2005) constructed refined proxies of contestability and also found that firm value is greater as distribution of control rights is more egalitarian.

This paper is organized as follows. Section 2 analyzes the theoretical linkages between blockholder control contestability and firm value. It also describes the baseline model that supports our testable hypothesis. Section 3 describes the data sources and sample selection of companies. Section 4 analyzes the structure and bias of corporate control for the 1996-2004 period. Section 5 evaluates how control contestability has affected firm value and performance and presents robustness checks on the basic results. Section 6 concludes.

\section{Control contestability and corporate governance}

Ever since the publication of Berle and Means (1932) there has been agreement that the main governance problem in listed corporations, given their dispersed ownership, is the separation of ownership and control in the sense that management controls the firm without any ownership stake. Work by Jensen and Meckling (1976) modeled the main agency problem arising from this separation. In the 1980s, the theoretical research of Shleifer and Vishny (1986) and Demsetz and Lehn (1985) established a second agency problem in listed corporations that arises between a large shareholder and a widely dispersed ownership.

How a large shareholder affects a firm's performance and valuation has elicited two opposite views. Some have argued that large shareholders have an incentive to seek private benefits of control and expropriate minority shareholders (tunneling). ${ }^{4}$ Others claim the incentive large blockholders have to monitor management yields good governance since their ownership stakes are high and most of the benefits of good governance will transfer to their own pockets, with the gains of better performance more than compensating for the costs of monitoring management. ${ }^{5}$

\footnotetext{
${ }^{3}$ In particular, La Porta et al. (1998) measure a country's investor protection through an anti-directors rights index that takes into account minority shareholders rights, such as cumulative and proxy voting, pre-emptive rights to new security issues, and percentage of votes needed for calling an extraordinary shareholder meetings, among others. The main result is that civil law countries perform better and their corporations exhibit greater market valuation and performance.

${ }^{4}$ See, Johnson, La Porta, Lopez-de-Silanes, and Shleifer (2000), Barclay and Holderness (1989) for early empirical research about private extraction of rents by large shareholders.

5 See Harris and Raviv (1988), Hart (1995), and Burkart, Gromb, and Panunzi (1997, 1998).
} 
Research on corporate governance has also focused on environments with more than one large blockholder. For instance, Bennedsen and Wolfenzon (2000) argue that control structures with multiple shareholders may be the most efficient ownership structure in environments with poor shareholder protection because controlling coalitions can align their incentives to prevent extraction of rents. ${ }^{6}$ Bloch and Hege (2001) also claim that multiple blockholders can compensate for the poor legal protection for minorities. They argue that the relevant concept of control is the contestability of the incumbent shareholder's position and that corporate control is contestable if the incumbent cannot increase the level of control rents without losing in a control contest. In their model, the presence of two large blockholders acts to limit private rent extraction and attracts the votes of the minority shareholders when proposals are contested.

Corporate ownership patterns in Latin America are similar to those observed in other markets, such as those in continental Europe and East Asia. They have high equity concentration and complex business group structures that take several forms (e.g., pyramids, cross-shareholdings, rings, and intricate webs). This allows controlling shareholders to leverage their voting power though business group affiliation and to deviate from the one-share-one-vote rule. Three other mechanisms also imply deviation from this principle: the issuance of non-voting shares, dividend-preferred share outstanding and dual shares. Corporate law in most of Latin America explicitly forbids the issue of dual shares, and some countries (e.g., Belgium and Chile) restrict cross-shareholdings and impose a cap on the issue of preferred stocks relative to shares outstanding. ${ }^{7}$

Table 1 shows the cash flow rights (the total votes implied by direct ownership) for the four largest shareholders in a sample of European, East Asian, Latin American and U.S. markets. It also presents the separation ratios, defined as the ratio of cash flow to voting rights. Voting rights are the total votes that a shareholder is entitled to on the basis of direct investment in a firm and indirect ownership. The table shows that ownership concentration is high except in the Japanese, U.S., U.K., and Korean markets. Corporate control is achieved in most countries by the top three blockholders under the one-vote-one-share rule. On average, the top three stakeholders hold $60 \%$ of a firm's equity. Yet, in most cases the largest blockholder does not have $51 \%$ of control or an absolute majority. The largest voting block, usually the controlling shareholder has $21 \%$ of cash flow rights on average in East Asian markets, $42 \%$ in continental Europe, and $48 \%$ in Latin America. In particular, the data shows that ownership concentration is lower in Colombia for the largest blockholder but higher at the second, third or four levels, in contrast to other Latin American economies in the sample.

The cash flow to voting rights ratios (a wedge proxy between ownership and control) exhibit low levels in all markets on average. Thus, separation is low when this indicator gets close to 1 , meaning that equity holders do not get additional voting power by indirect ownership. There is a full separation when that ratio tends to 0 , as in the case of a shareholder who exerts control with no direct investment. The international evidence summarized sug-

\footnotetext{
${ }^{6}$ Specifically, they state that "the greater the cash flow possessed by the controlling coalition, the more this coalition internalizes the costs of its actions. Hence the fewer costly private benefits it extracts" (p. 115). They called this the alignment effect. However, they also model a type of coalition that can dominate over the alignment effect. They argue that this is a negative effect since, among the many coalitions that can arise, the one with the smallest joint cash flow stake will take control and will have an incentive to extract private rents from the largest possible group of shareholders excluded from the coalition.

${ }^{7}$ For example, these are the cases of Belgium and Chile. In Colombia, there is no restriction to cross-shares and preferred stocks have a cap of $50 \%$ firm equity.
} 
Table 1

Corporate ownership: cash flow rights (direct ownership) and separation ratios for larger stakeholders in non-financial listed firms for selected countries

\begin{tabular}{|c|c|c|c|c|c|c|c|}
\hline Country & Year & $N$ & CR1 & CR2 & CR3 & CR4 & $\begin{array}{l}\text { Cash flow/ } \\
\text { voting rights }\end{array}$ \\
\hline Austria & 1996 & 95 & 47.16 & 57.76 & 60.66 & & 0.8510 \\
\hline Belgium & 1999 & 120 & 35.14 & 45.44 & 49.94 & 50.64 & 0.7790 \\
\hline France & 1996 & 674 & 46.68 & 55.68 & 60.68 & 63.18 & 0.9300 \\
\hline Germany & 1996 & 372 & 49.60 & 52.50 & 53.10 & & 0.8420 \\
\hline Italy & 1996 & 204 & 38.33 & 46.03 & 49.53 & 50.38 & 0.7430 \\
\hline Spain & 1995 & 193 & 32.13 & 40.08 & 47.06 & 49.96 & 0.9410 \\
\hline UK & 1992 & 207 & 14.44 & 21.74 & 27.74 & 33.00 & 1.0000 \\
\hline USA-NYSE & 1996 & 1309 & 8.50 & 12.20 & 14.00 & 14.15 & 0.9596 \\
\hline Hong-Kong & 1996 & 330 & 24.30 & - & - & - & 0.8820 \\
\hline Indonesia & 1996 & 178 & 25.61 & - & - & - & 0.7850 \\
\hline Japan & 1996 & 1117 & 6.90 & - & - & - & 0.6020 \\
\hline Korea & 1996 & 211 & 13.96 & - & - & - & 0.8580 \\
\hline Malasya & 1996 & 238 & 23.89 & - & - & - & 0.8530 \\
\hline Philipines & 1996 & 99 & 21.34 & - & - & - & 0.9080 \\
\hline Singapore & 1996 & 211 & 20.19 & - & - & - & 0.7940 \\
\hline Tawian & 1996 & 92 & 15.98 & - & - & - & 0.8320 \\
\hline Thailand & 1996 & 135 & 32.84 & - & - & - & 0.9410 \\
\hline Argentina & 2003 & 54 & 60.70 & - & - & - & 0.9650 \\
\hline Brazil & 1998 & 240 & 47.00 & - & 59.00 & - & 0.6812 \\
\hline Chile & 1998 & 195 & 46.00 & - & 55.00 & - & 0.8070 \\
\hline Colombia & 1998 & 149 & 37.90 & 53.80 & 63.34 & 69.60 & 0.9483 \\
\hline Mexico & 1996 & 20 & - & - & 64.00 & - & 0.8225 \\
\hline \multicolumn{2}{|c|}{ Average Continental Europe } & 41.51 & 49.58 & 53.50 & 53.54 & 0.85 & \\
\hline \multicolumn{2}{|c|}{ Average East-Asia } & 20.56 & & & & 0.83 & \\
\hline \multicolumn{2}{|c|}{ Average Latin America } & & 47.90 & & 60.34 & & 0.84 \\
\hline \multicolumn{2}{|c|}{ Colombia/average, continental Europe } & 0.9131 & 1.0851 & 1.1840 & 1.3000 & & \\
\hline
\end{tabular}

This table presents the cash flow rights (direct ownership) and concentration ratios up to the four largest stakeholders and the separation between ownership and control proxied by the ratio of cash flow to voting rights. Continental Europe: CR1 refers to the ultimate controlling blockholder cash flow rights according to Faccio and Lang (2002); CR2 to CR4 adds the direct votes for the second to the fourth voting blocks reported in Barca and Becht (2000). Separation ratios are at the controlling blockholder's level reported in Faccio and Lang (2002); USA and UK refer to direct cash flow rights of main blockholders according to Barca and Becht (2000). Separation ratios are from La Porta et al. (1999); East Asia: CR1 is the cash flow rights of controlling blockholders. Separation ratios are at controlling blockholders level. Data from Claessens et al. (2000); Argentina and Chile: CR1 refers to direct equity of the controlling blockholder. Separation ratios derived from total voting rights at controlling shareholder level. Data from Bebczuk (2007) and Leffort and Walker (2007); CR3 is the total voting rights of the three largest blockholders for Chile; Mexico: Cash flow rights of the three largest stakeholders in the 10 largest publicly traded companies, data from La Porta el al. (1998 and 1999). Brazil and Colombia: refer to direct votes from direct equity ownership (cash flow rights) for the larger shareholders. Separation ratios estimated from total voting rights measured by total direct plus indirect ownership. Data for Brazil is from Leal and Carvalhal-da-Silva (2007); the estimates for Colombia are our own.

gests that the separation between ownership and control is 0.85 , which means the largest shareholder needs $43 \%$ of direct votes to get a simple majority of $51 \%$ at a general meeting.

Two opposite corporate structures explain this result. In the first instance, equity is concentrated in hands of few large shareholders who can achieve an absolute majority by making a simple voting pact. There is no need for further voting leverage, and monitoring a firms' management becomes 
costless. However, the risk of outright expropriation increases for minorities. For instance, in Colombia the top four shareholders have $70 \%$ of direct equity and the top 10 shareholders have $85 \%$. The mean for minorities is $15-25 \%$ of a firm's equity. Thus boards can declare earnings retentions and increase their portfolio holdings in related firm investments or implement a policy of transfer prices to related suppliers and get extra dividend payments through diversion of a firms' cash flow.

This does not imply that there are no cases of voting leverage within business groups around the world and wide separation of controlling blockholders. For example, the largest Italian conglomerate is the Agenlli group. Bianchi, Bianco, and Enriques (2001) report that this family controls more than 50 firms through pyramiding its investments in one holding company (ISI) and FIAT Corporation. Claessens et al. (2000) give an account of the Ayala group, the largest conglomerate in the Philippines, which controls by pyramiding 34 affiliated firms through Ayala Corporation, an investment firm that is the largest listed company by market capitalization on the Manila stock exchange. Gutiérrez et al. (2008) show how the Santo Domingo family in Colombia exerted control over 50 companies through two investment firms (Union de Valores and Valores Bavaria) until 2002.

A second corporate structure results when ownership is atomized across small shareholders. This is the case in widely held firms where an individual's total votes are derived from direct investment in a company's equity. This holds mainly in the U.S. and the U.K. markets, where the typical agency problem arises between management and the shareholders because there is no direct monitoring. This implies that executives and directives enjoy excessive internal power and discretion. According to Barca and Becht (2001) more than half of U.S. non-financial incorporated companies listed on the NYSE do not have a single blockholder with a stake of $5 \%$ or more. Hence, governance in U.S. public corporations is not driven by the existence of controlling blockholders. Fig. 1 summarizes the different outcomes that result from the separation between ownership and control, and charts the role of contestability among multiple large blockholders.

Despite the many country case and cross-section studies that followed the La Porta et al. (1999) study of corporate control, only a few have tried to test how control contestability relates to firm value. In their study of Spanish firms, Gutiérrez and Tribó (2004, p. 10) state that "performance improves as the control group's ownership stake increases and, for a given ownership stake, as the number of members increases." They also found that minority expropriation is more generalized in closely held corporations than in listed companies. Looking at Finnish firms, Maury and Pajuste (2005) studied the effect of multiple large shareholders on firm valuation and developed a model consistent with the Bennedsen and Wolfenzon (2000) insight that the marginal cost of extracting private rents can be high when there are multiple blockholders. This means that higher contestability (by other large blockholders) will lead to a better firm valuation.

\subsection{The baseline model and the hypotheses on control contestability}

The baseline model of control contestability is borrowed from La Porta, Lopez-de-Silanes, Shleifer, and Vishny (2002), who modeled managerial rent extraction, and from Maury and Pajuste (2005) who extended the baseline model to reveal contestability behavior more explicitly among multiple large shareholders. The model has two main assumptions: that the existence of multiple large shareholders can reduce profit diversion (i.e., that control contestability is value-enhancing) and that diversion of profits by the controlling coalition is costly. 


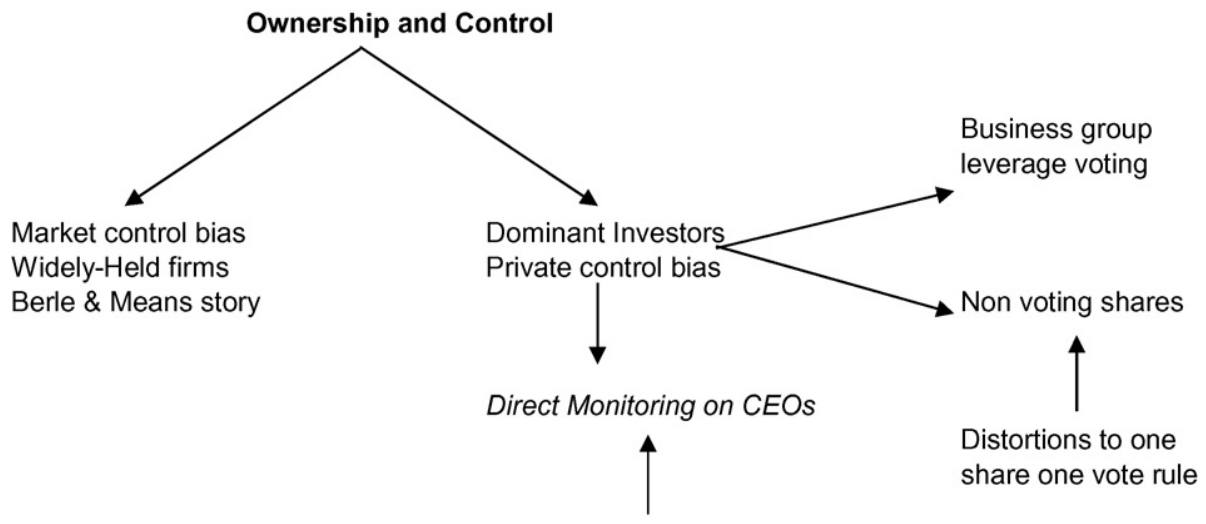

High ownership concentration

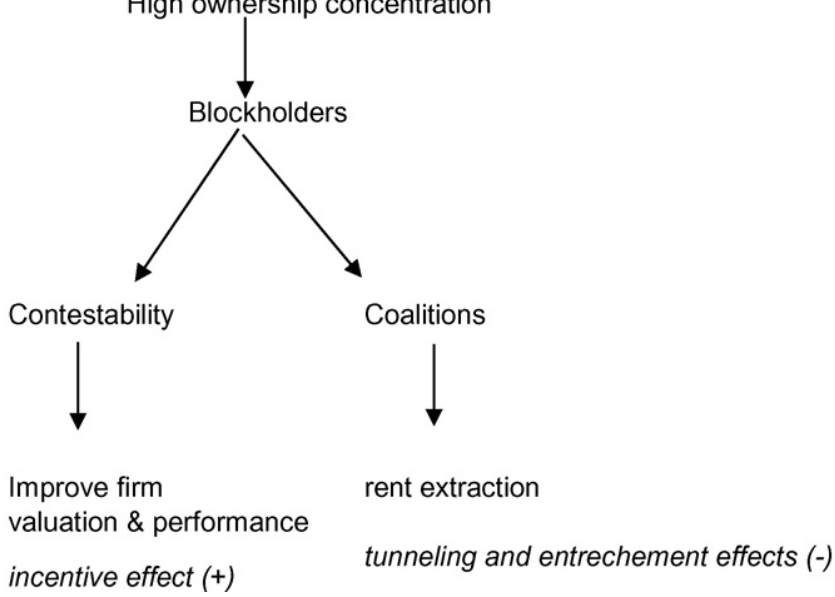

Fig. 1. Ownership and control.

Under efficient capital markets the capital asset pricing model (CAPM, Sharpe, 1964) states that, in equilibrium, the return of any risky asset is given by the following condition

$$
r_{i}-\beta_{i}\left(r_{\mathrm{m}}-r_{\mathrm{f}}\right)=r_{j}-\beta_{j}\left(r_{\mathrm{m}}-r_{\mathrm{f}}\right)=\ldots=r_{\mathrm{n}}-\beta_{\mathrm{n}}\left(r_{\mathrm{m}}-r_{\mathrm{f}}\right)
$$

where $r_{i}$ is the return of asset $i ; \beta_{i}$ is the asset $i$ 's systematic risk; $r_{\mathrm{m}}$ is the market return; $r_{\mathrm{f}}$ is the risk-free asset. In other words, in equilibrium, the returns of all risky assets are equal once they have been adjusted by risk. This condition can be rewritten by means of its relation to a risk-free asset; therefore

$$
r_{i}-\beta_{i}\left(r_{\mathrm{m}}-r_{\mathrm{f}}\right)=r_{\mathrm{f}} \quad \text { or } \bar{r}_{i}=r_{\mathrm{f}}+\beta_{i}\left(r_{\mathrm{m}}-r_{\mathrm{f}}\right)
$$

which is the CAPM equation that defines the market equilibrium return of a risky asset $i$.

Let $s$ be the share of profit diversion of firm $i$ 's dominant coalition, $\bar{r}_{i}$ be the equilibrium return of firm $i$ equity, and

$$
r_{i}=\bar{r}_{i}(1-s)
$$


Eq. (3) states that firm i's equity return is less than its equilibrium level if there is a diversion of profits, $s>0$. Multiplying equity return by an investment amount $I$ of new projects and knowing that there is a voting pact among large shareholders with a weight $\alpha$ of firm equity, one gets the total coalition cash flow after profit diversion from firm $i$ 's project; that is

$$
\alpha(r I)=\alpha[\bar{r}(1-s)] I
$$

where the subscript $i$ has been removed to simplify the exposition.

The dominant coalition can internalize the benefits of diverting firm profits before distributing the rest, if any, in dividends to the outside coalition shareholders. Thus, the benefits of expropriation of the controlling coalition, $\pi^{\mathrm{c}}$, are

$$
\pi^{\mathrm{c}}=s(\bar{r} I)-c(s, v)(\bar{r} I)
$$

The first term of Eq. (5) is the diverted dividend, while the second term represents the cost of rent extraction. Because the model assumes that diversion is costly, the cost-of-theft function $c(s, v)$ - is an increasing function of the parameter $s$. It therefore follows that $c_{\mathrm{S}}>0$ and $c_{\mathrm{SS}}>0$. The first inequality means the marginal cost of stealing is positive, while the second means that the marginal cost rises as more is stolen.

The cost function also depends on variable $v$, which is the coalition voting power. As long as the voting power of the controlling block increases, it can reduce the cost of rent extraction attributable to better rent hiding, easy consensus, and the additional knowledge that each member contributes to the coalition. Thus, the marginal cost of rent diversion is negative as long as the voting power increases, given a level of diverted rents; that is, $c_{\mathrm{SV}}<0 .{ }^{8}$

The dominant coalition maximizes its value function, which is the sum of the diverted cash flows of the firm's projects and the benefits of rent extraction. That is

$$
\operatorname{Max}_{S} V^{\mathrm{C}}=\alpha[(1-s) \bar{r}] I+s(\bar{r} I)-c(v, s)(\bar{r} I)
$$

where $s$ denotes the share diversion that is the control variable of the program.

The first order condition of Eq. (6) is given by

$$
c_{S}(s, v)=1-\alpha
$$

Eq. (7) states that the optimal share diversion $s^{*}$ is defined when the marginal cost of profit diversion equals the outside coalition votes. The higher the coalition's cash flow rights, the lower will be the marginal cost of rent diversion and therefore the lower will be $s^{*}{ }^{9}$ In other words, high cash flow rights of the majority coalition lessen expropriation from minority shareholders because there is a lesser amount of rents to divert.

Maury and Pajuste (2005) extend this result and model control contestability more explicitly by including a conditional probability that large shareholders outside the dominant coalition can recover part of the extracted profits, Prob (recover/s) $=k$. Therefore, Eq. (7) becomes

$$
c_{s}(s, v)=(1-\alpha)(1-k)
$$

\footnotetext{
${ }^{8}$ In La Porta et al. (2002) this variable captures the quality of investor protection.

${ }^{9}$ For instance, if the cost-of-theft function is quadratic, it can be shown that $s^{*}=(1-\alpha) / 2$.
} 
From Eq. (8) the comparative statics of the model follows; that is

$$
\frac{\partial s *}{\partial \alpha}=\frac{-(1-k)}{c_{\mathrm{ss}}}<0 \text { and } \frac{\partial s *}{\partial k}=\frac{-(1-\alpha)}{c_{\mathrm{ss}}}<0
$$

Thus, optimal share diversion $s^{*}$ decreases when contestability from outside blockholders increases, $k>0$, and when their own cash flow rights increase because they have fewer rents to extract. This leads to the first working hypothesis.

Hypothesis 1. Firm valuation and performance should increase as contestability of the controlling coalition's power increases.

The second hypothesis is related to the tunneling effect captured by the separation of equity and voting rights of large shareholders. When a controlling shareholder leverages its voting power through pyramids within a business group, it has incentives to extract rents. In addition, an increase of the voting power of the controlling coalition allows for better coordination among its members and also may provide better knowledge that makes profits diversion less costly. Differentiating Eq. (8) with respect to voting power $v$ and assuming that share diversion $s$ and the probability of recovering extracted profits $k$ by the outsider voting block is endogenous to $v$, one gets

$$
\frac{\partial s *}{\partial v}=\frac{-(1-\alpha)(\partial k / \partial v)-C_{\mathrm{sv}}}{C_{\mathrm{ss}}}>0
$$

The first term on the numerator depicts the negative effect that an increase of voting power has on contestability. The second term captures the positive effect that voting power has on reducing the costs of diverting firm resources. The overall effect is positive; therefore the second working hypothesis is

Hypothesis 2. Larger separation between ownership rights and control rights will lead to a decrease in firm valuation.

Hypothesis 2 implies that high voting power relative to cash flow rights gives more discretion to ultimate owners. In the next section we describe the data characteristics and sample selection.

\section{Data and sample selection}

We collected data on financial statements and ownership structures of Colombian listed companies during 1996-2004. The assembled dataset of corporate shareholders comes from the Superintendence of Securities (Superintendencia de Valores, SVAL) and the Superintendence for Commercial Societies (Superintendencia de Sociedades, SSOC). These two institutions are respectively responsible for inspecting and overseeing equity-issuing corporations and larger unlisted firms. The SVAL ownership database is based on National Equity Registry Forms (Registro Nacional de Valores e Intermediarios, RNVI), which record information on a company's top 20 shareholders. This form is mandatory for all equity issuers that are under the oversight of SVAL and must be updated on a yearly basis. The form also records the names of board members, the number of outstanding shares, the number of preferred dividend shares and the nominal value for each type of shares. ${ }^{10}$

\footnotetext{
${ }^{10}$ In 2005 the Superintendence of Securities and the Banking Superintendence were merged to set up today's Financial Superintendence with the purpose of centralizing financial and capital markets regulation. The ownership information of
} 
The database on ownership and control in Colombian corporations was borrowed from the study of Gutiérrez et al. (2008). This covered through year 2002, and basic ownership information was then updated for years 2003 and 2004. Having a panel dataset of ownership improves the analysis because we can capture ownership dynamics, an element not usually included in international studies of corporate control. At most, this database provides information on the first property layer. To complete a company's second, third, and further ownership layers, we assembled a dataset of information on major shareholders of unlisted firms who showed up as major shareholders of a listed corporation and who were affiliated with a business group. This information came from the SSOC records of the largest stakeholders for non-public corporations, as well as from partnership distributions for limited liability and all other legal types of firms. Hence, we could assemble financial and ownership information on 245 listed companies for the 1996-2004 period, and gather complementary ownership information for 431 unlisted firms to trace ownership control from year 1996 to year 2002 of each listed company included in the study sample.

Following Maury and Pajuste (2005) we focus on the role of blockholders, so we include only firm years that had a blockholder with at least $10 \%$ of cash flow rights. The RNVI do not provide information about investor voting. Therefore, following the portfolio methodology proposed by Baldone, Brioschi, and Paleari (1997) and applied in the studies collected by Barca and Becht (2001), we estimate shareholders' integrated ownership as a proxy of investors' control rights for companies affiliated with business groups under the one-share-one-vote rule. ${ }^{11}$ For independent companies we followed the manual adding procedure under the $20 \%$ cut-off proposed in La Porta et al. (1999). ${ }^{12}$ The maximum number of firm year observations that satisfy all the criteria amounted to 1092, and the number of firms up to 233, although that figure changes as we use different variables of analysis. ${ }^{13}$ Hence, the panel is unbalanced.

Table 2 summarizes the number of equity-issuing companies in our working sample registered with SVAL during 1996-2004. The data clearly show that delisting has been a common pattern in Colombia, and this accords with what has been observed in other Latin American markets. Firm delisting was intensive during the second half of the 1990s, reaching a peak during 1998-1999 when the Colombian economy was in the midst of the worst recession in 80 years. Hence, listed companies in the sample dropped from 152 to 94 firms, a drop close to $40 \%$ in 9 years.

\section{Corporate control}

It is well known that corporate ownership and control is highly concentrated in Colombia. This fact has been tied to the formation of conglomerates and business groups from the 1950s to the late 1970s, when vertical control provided the incentive for controlling productive chains from

\footnotetext{
listed companies is publicly available. In contrast, the ownership data from SSOC for all types of closely held companies is subject to statistical reserve.

${ }^{11}$ See Gutiérrez et al. (2008) for further details regarding the used shareholders' dataset, for an explanation of the portfolio approach and results for the case of Colombia in measuring firm voting rights.

${ }^{12}$ We excluded all companies subject to special regulations, such as public utilities, financial intermediaries, educational institutions, and livestock funds, since their performance might be affected by regulation and State property participation, and results might not be comparable. In addition, we discarded firm year observations that did not have a blockholder as well as those firms lacking reliable information on stock prices, financial statements or equity distribution. The listing status criterion refers to whether a listed firm was still listed by the end of 2004 or had canceled its equity registry and was delisted.

${ }^{13}$ For instance, Tobin's Q can be calculated only if firm valuation can be assessed. This requires that market value of equity be known, which can happen only if the stock of the firm was traded at least once during a year.
} 
Table 2

Number of firms in the study sample by listing status and economic activity

\begin{tabular}{|c|c|c|c|c|c|c|c|c|c|}
\hline Status/ISIC group & 1996 & 1997 & 1998 & 1999 & 2000 & 2001 & 2002 & 2003 & 2004 \\
\hline DE-LISTED & 15 & 29 & 29 & 22 & 5 & 14 & 6 & 3 & 1 \\
\hline LISTED & 137 & 129 & 120 & 103 & 99 & 97 & 96 & 94 & 93 \\
\hline Agriculture, forestry and fishing & 5 & 5 & 4 & 3 & 2 & 3 & 4 & 4 & 4 \\
\hline Mining and quarrying & 4 & 4 & 3 & 3 & 2 & 2 & 2 & 2 & 2 \\
\hline Manufacturing & 78 & 76 & 68 & 62 & 56 & 61 & 54 & 51 & 48 \\
\hline Construction & 8 & 9 & 8 & 6 & 4 & 4 & 4 & 3 & 3 \\
\hline Wholesale, retail trade, lodging & 27 & 23 & 19 & 13 & 11 & 10 & 9 & 7 & 6 \\
\hline Transport, storage and communication & 10 & 13 & 16 & 11 & 8 & 7 & 8 & 9 & 9 \\
\hline Financing, insurance, real state & 11 & 18 & 22 & 19 & 14 & 17 & 15 & 15 & 16 \\
\hline Community, social and personal services & 8 & 8 & 7 & 7 & 7 & 7 & 6 & 6 & 6 \\
\hline Other non-classified business activities & 1 & 2 & 2 & 1 & & & & & \\
\hline Total sample & 152 & 158 & 149 & 125 & 104 & 111 & 102 & 97 & 94 \\
\hline
\end{tabular}

Notes: Delisted firms are those that cancelled their Registry Equity Form from the Superintendence of Securities between 1996 and 2004. Source: Financial Superintendence-National Equity Registry Forms.

upstream to downstream industries. Most of these groups started as family businesses and then became corporate groups with strategic investments in their core business. Gutiérrez et al. (2008) show that there are four facts regarding corporate ownership and control for the entire sample of listed companies during the 1996-2002 period:

(1) Corporate ownership is highly concentrated. In almost all companies the four largest shareholders have more than $51 \%$ of a firm's cash flow rights.

(2) Ownership concentration has increased.

(3) Separation ratios are low for large stockholders, although there is evidence of full separation in some cases at controlling shareholders' level.

(4) Investment firms play a central role as controlling shareholders.

Regarding the first three elements, Table 3 summarizes the core results of the ownership and control statistics for the sample of firms that report at least one voting block. The findings conform to the above facts and, more important, the pattern is reinforced with the updated measurements that include the years 2003 and 2004. Ownership concentration is high and has risen in time, mainly for the largest blockholder, whose mean stake rose from 36.3 by the end of 1990s to 43.3 for the 2000-2004 period. The median, nonetheless, decreased between periods, signaling a change as the stake distribution becomes less skewed and more uniformly distributed (Fig. 2). The weight of smaller voting blocks remained fairly constant across periods.

Also, corporate ownership is in the hands of the top three or four largest shareholders. The mean of the concentration ratio of the top four stakeholders (CR4) increased from 67.9 to $72.9 \%$ between periods. Fig. 3 plots the histogram for the top four shareholders. The distribution is clearly left-skewed, meaning that cash flow rights are concentrated among the higher percentiles. In particular, the frequency distribution has two peaks. One shows that in $17 \%$ of the firm year observations the top four shareholders have between 72 and $82 \%$ of equity. Moreover, in about $25 \%$ of the firm year observations the four largest shareholders hold above $92 \%$ of companies' equity. Therefore, control contestability across voting blocks must take place among the top four players; otherwise, they must form a voting coalition of some kind to control boards. 
Table 3

Ownership and corporate control statistics

\begin{tabular}{|c|c|c|c|c|}
\hline \multicolumn{3}{|l|}{ Concentration indices } & \multicolumn{2}{|c|}{ Separation ratios: equity to voting rights } \\
\hline Indicator/statistic & 1996-99 & 2000-2004 & 1996-99 & 2000-2004 \\
\hline Number of firms & 146 & 102 & & \\
\hline \multicolumn{3}{|c|}{ Share largest shareholder CR1 } & \multicolumn{2}{|c|}{ Largest voting block } \\
\hline Mean & 0.3628 & 0.4333 & 0.9592 & 0.9522 \\
\hline Median & 0.4855 & 0.3712 & 1.0000 & 1.0000 \\
\hline Standard deviation & 0.2161 & 0.2467 & 0.1020 & 0.1181 \\
\hline Min & 0.1027 & 0.1066 & 0.4603 & 0.4321 \\
\hline Max & 0.9584 & 0.9761 & 1.0000 & 1.0000 \\
\hline \multicolumn{3}{|c|}{ Share top four shareholders: CR4 } & \multicolumn{2}{|c|}{ Second-largest voting block } \\
\hline Mean & 0.6794 & 0.7296 & 0.9082 & 0.8384 \\
\hline Median & 0.8708 & 0.7697 & 1.0000 & 1.0000 \\
\hline Standard deviation & 0.2209 & 0.2198 & 0.2003 & 0.2769 \\
\hline Min & 0.2127 & 0.2704 & 0.1753 & 0.0834 \\
\hline Max & 1.0000 & 1.0000 & 1.0000 & 1.0000 \\
\hline \multicolumn{3}{|c|}{ Share Second-largest voting-block: Equity 2} & \multicolumn{2}{|c|}{ Third-largest voting block } \\
\hline Mean & 0.1590 & 0.1544 & 0.8883 & 0.7977 \\
\hline Median & 0.2012 & 0.1335 & 1.0000 & 1.0000 \\
\hline Standard deviation & 0.0901 & 0.0983 & 0.2244 & 0.3038 \\
\hline Min & 0.0057 & 0.0071 & 0.0162 & 0.0154 \\
\hline Max & 0.4876 & 0.4862 & 1.0000 & 1.0000 \\
\hline \multicolumn{3}{|c|}{ Share third-largest voting block: Equity 3} & \multicolumn{2}{|c|}{ Fourth-largest voting block } \\
\hline Mean & 0.0947 & 0.0867 & 0.8528 & 0.7535 \\
\hline Median & 0.1221 & 0.0767 & 1.0000 & 0.9985 \\
\hline Standard deviation & 0.0556 & 0.0643 & 0.2593 & 0.3299 \\
\hline Min & 0.0000 & 0.0000 & 0.0000 & 0.0001 \\
\hline Max & 0.3124 & 0.3066 & 1.0000 & 1.0000 \\
\hline \multicolumn{5}{|c|}{ Share fourth-largest voting-block: Equity 4} \\
\hline Mean & 0.0629 & 0.0552 & & \\
\hline Median & 0.0881 & 0.0512 & & \\
\hline Standard deviation & 0.0408 & 0.0419 & & \\
\hline Min & 0.0000 & 0.0000 & & \\
\hline $\operatorname{Max}$ & 0.1987 & 0.1749 & & \\
\hline
\end{tabular}

Source: Our own estimation based on a dataset compiled from SVAL National Equities Registry Forms.

These statistics imply evidence of control contestability involving the two largest shareholders because on average the data show that the median of direct votes within larger stakeholders decreased in the 2000-2004 period, from 48\% in the second half of the 1990 s to $37 \%$ for the largest blockholder, from 20 to 13\% for the second largest blockholder, and from 12 to $7.6 \%$ for the third largest blockholder. To get firm control, the largest stakeholder needs to form a coalition with the second largest voting block. Further, in many cases the third or even fourth largest block can contest the top two blocks because their marginal votes are needed for $51 \%$ of control. These results are reinforced by the low separation ratios between cash flow rights and voting rights. This is 0.95 on average for the largest blockholder, which means this shareholder needs at least $48.5 \%$ of direct ownership to guarantee firm control of $51 \%$. 


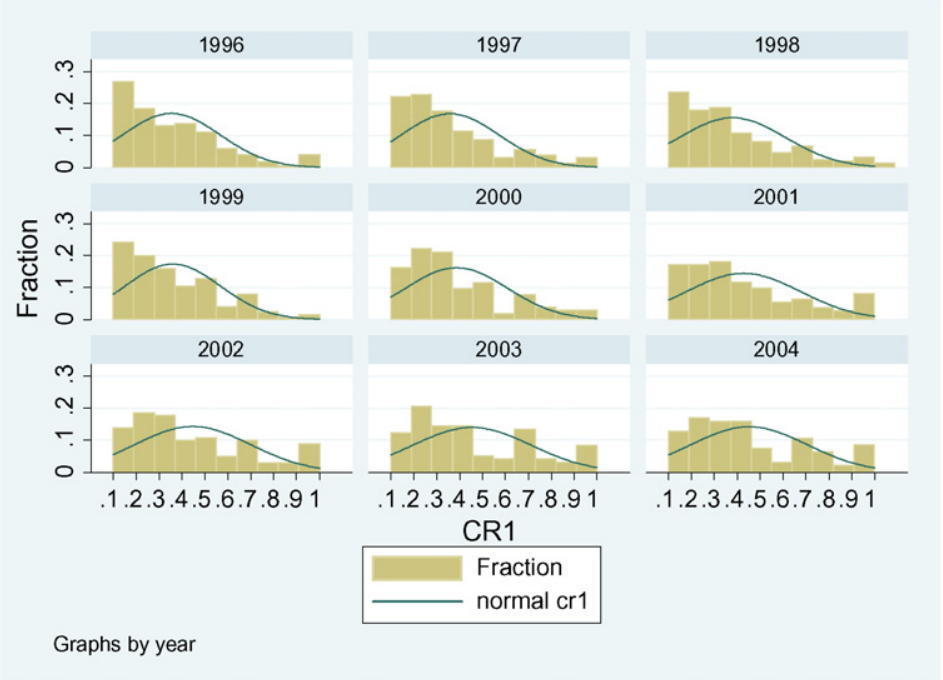

Fig. 2. Histogram evolution of the largest voting block by year. Source: Our own estimation based on a dataset compiled from SVAL National Equities Registry Forms.

Nevertheless, separation between ownership and control has increased over time. The mean for the third and fourth largest blockholders was 0.89 and 0.85 , respectively, during the 1990s, 0.79 and 0.75 , respectively, during 2000-2004. Thus, a large shareholder would need at least $38.3 \%$ of direct ownership for an absolute majority on a firm's board under the one-share-onevote regime. Evidence of full separation at the third- and fourth-largest shareholder level means that their voting rights are fully leveraged by business group structures and there is no need for

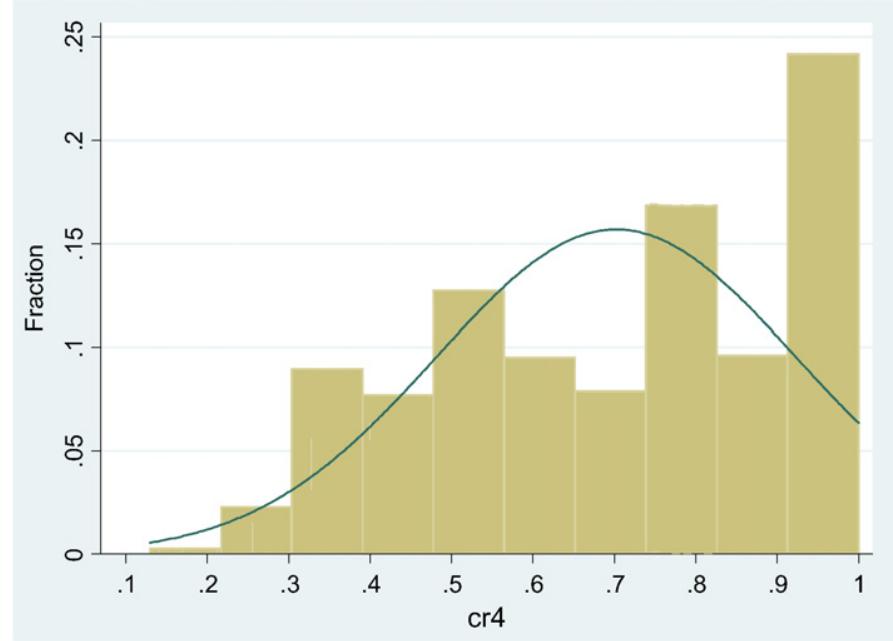

Fig. 3. Histogram - top four shareholders, 1996-2004. Source: Our own estimation based on a dataset compiled from SVAL National Equities Registry Forms. Note: The total sample consists of 1092 firm-year observations. 


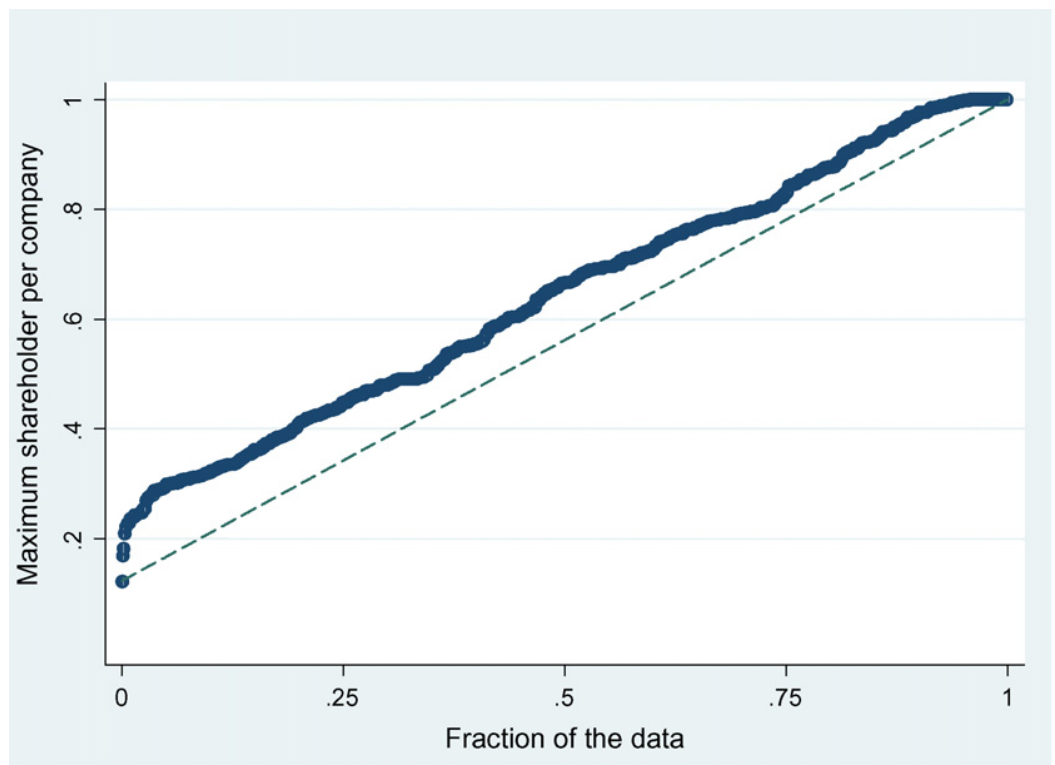

Fig. 4. Percentile plot of the three largest voting blocks 1996-2004. Source: Our own estimations based on a assembled dataset from SVAL National Equity Registry Forms.

direct equity investment to become a voting block. The table shows a minimum value of 0 for the fourth-largest voting block and values of less than $2 \%$ for the third-largest shareholder.

To illustrate the corporate control direction bias, we use the percentile rank functions for the largest direct voting block and for the top two to four direct voting blocks. The intuition behind these graphs is to determine how asymmetric ownership is. Concentration measures have a maximum value of 1 , representing $100 \%$ of a company's net worth. If the distribution is uniform, with equally proportioned stakes across firms, its percentile rank function would be the $45 \%$ degree line. In other words, there is no dispersion with respect to the distribution median. A percentile rank function below the $45 \%$ degree line indicates low ownership concentration along with low levels of blockholder power. Control declines more than proportional with a reduction in ownership are indicative of a market control bias. A function above the $45^{\circ}$ line represents high ownership concentration and blockholder power. This is associated with owner private bias, with declines in control less than proportional to a reduction in ownership. Fig. 4 is a percentile plot for the top three blockholders (CR3) for the total sample of 1092 firm year observations between 1996 and 2004. Control bias lies above the straight line that represents an even distribution between firms and equity share. ${ }^{14}$ At the $50 \%$ fraction of data, the three largest shareholders have around $60 \%$ of direct votes. The implication on control is straightforward: a coalition among the top three stakeholders guarantees absolute firm control. At the same time the second- and third-largest equity holders have an incentive to contest the power of the largest voting block.

Table 4 describes the relation of block ownership with firm valuation and strengthens the results for shareholders' control bias and separation ratios. There was one blockholder in about 219 firm-year observations out of $686(31.9 \%)$. This increased to $36.4 \%$ for two blockholders,

\footnotetext{
14 The straight line in this case is not the $45^{\circ}$ line because the data sample is truncated at the $10 \%$ equity level. Otherwise, the percentile plot must yield the $45^{\circ}$ line to represent the set of even points in the Cartesian plane.
} 
Table 4

Blockholders and median Tobin's Qs

\begin{tabular}{|c|c|c|c|c|c|c|c|c|c|}
\hline & \multicolumn{2}{|c|}{ One block } & \multicolumn{2}{|c|}{ Two blocks } & \multicolumn{2}{|c|}{ Three blocks } & \multicolumn{2}{|c|}{ Four blocks } & \multirow[t]{2}{*}{ Total $N$} \\
\hline & $N$ & Median Tobin's Q & $N$ & Median Tobin's Q & $N$ & Median Tobin's Q & $N$ & Median Tobin's Q & \\
\hline \multicolumn{10}{|l|}{ Panel A: block owners and Tobin's Q values } \\
\hline Equity $1+$ Equity $2+$ Equity $3<50[1]$ & & & & & & & 58 & 1.003 & \\
\hline Equity $1+$ Equity $2+$ Equity $3>50[2]$ & & & & & & & 36 & 0.819 & \\
\hline Equity $1+$ Equity $2<50$ & & & 153 & 0.753 & 62 & 0.916 & 27 & 0.847 & 329 \\
\hline Equity $1+$ Equity $2>50[4]$ & & & 97 & 0.751 & 61 & 0.780 & 67 & 0.893 & 357 \\
\hline Equity $1<50[5]$ & 87 & 0.839 & & & & & & & \\
\hline Equity $1>50[6]$ & 132 & 0.722 & & & & & & & \\
\hline Total & 219 & 0.761 & 250 & 0.752 & 123 & 0.894 & 94 & 0.877 & 686 \\
\hline \multicolumn{10}{|c|}{ Panel B: Z-statistics for differences in medians } \\
\hline Test:[1] vs. [2] & & & & & & & & 1.431 & \\
\hline Test: [3] vs. [4] & & & & -0.085 & & 1.396 & & $-1.809^{*}$ & \\
\hline Test: [5] vs. [6] & & $1.844 *$ & & & & & & & \\
\hline
\end{tabular}

Notes: The table shows the number of firm-year observations, voting power and firm valuation in each category of controlling blockholders. The total sample is formed by 233 listed firms subject to oversight by the Superintendence of Securities in the 1996-2004 period. A blockholder is defined as a shareholder with at least 10\% of cash flow rights or direct ownership.

Source: Our own estimation based on a dataset assembled from SVAL National Equity Registry Forms. 
decreased to 17.9 and $13.7 \%$, respectively, for three and four blockholders. The results suggest that firm valuation proxied by Tobin's $Q$ varies with the existence of several voting blocks and whether these have enough voting power to attain the majority rule of $51 \%$. Firm valuation is greater in firms with three or four blocks. The median of Tobin's Q moves from 75 to $88 \%$ on average in companies that have more than two voting blocks. Further, firm valuation is lower if the largest or the two largest shareholders have a majority. Median tests are significant at $10 \%$. For the remaining cases, the null hypothesis of differences in firm valuation if blocks have a majority is not rejected Thus, the findings partially support our working hypothesis of control contestability as well as rent extraction and tunneling by either the controlling shareholder or a voting coalition. ${ }^{15}$

\section{Econometric analysis}

\subsection{Definition of variables}

The main valuation measure is Tobin's Q, which is measured following Black, Jang, and Kim (2006), who defined it as the ratio between market value and book value of assets. Colombian accounting and tax regulations require that all firms update their book values yearly, so the use of book value of assets must be very close to replacement costs. Market value of assets was estimated as the sum of book value of debt plus book value of preferred stocks and market value of common stock. In turn, the yearly market value of common stocks was calculated as the product of the average market price times the number of common stocks. The value of liabilities (in Colombian pesos) was taken as the book value of debts.

Some studies have suggested that Tobin's $Q$ is not a good proxy for firm value in emerging economies because of measurement problems, the limited offer of stocks, the non-competitiveness of the stock market and problems with the measurement of replacement cost of assets (see Claessens et al., 2000). Instead, they propose related value measures, such as the market-to-book ratio (MTBR), defined as the ratio between market value of common stock (as defined above) and book value of common stock, the latter estimated as the sum of the book value of assets minus the book value of liabilities and preferred stock. Another proposed value measure is market-to-sales ratio (MTS), market value of common stock divided by sales. The market value of equity, i.e., the yearly average, for the period 1996-2004 was provided by the Colombian Stock Exchange.

Because the sample includes firms whose stocks were not traded at least once during a year, their market value could not be obtained and so we used returns on assets (ROA) and returns on equity (ROE) as alternative performance variables. Contestability variables were constructed following Maury and Pajuste (2005), who used four proxies. The first is the Herfindal concentration index (HI_concentration) that captures the effect of voting block power. A second variable is the differences in the Herfindal indices (HI_differences), defined as the sum of the squares of the differences between the first and second largest voting stakes, the second and the third largest voting stakes and the third and fourth largest voting stakes. ${ }^{16}$ These variables capture the actual contestability that the largest blockholder faces when unable to control the company directly. ${ }^{17}$

\footnotetext{
15 To see whether using control rights (direct and indirect ownership) instead of ownership rights produced different results, we repeated the tests, but none was statistically significant. This was surprising since medians of Tobin's Q were almost equal across the different number of blocks. Similar tests were performed for MTBR, MTSR, ROE and ROA.

16 The formulas are: HI_concentration $=\sum_{i=1}^{4}\left(\text { Votes }_{i}\right)^{2}$ and HI_differences $=\sum_{i=1}^{4}\left(\text { Votes }_{i}-\text { Votes }_{i+1}\right)^{2}$.

17 Both measures are transformed into logarithms to control for distribution skewness.
} 
Their expected relation with firm value is negative because, as voting power among the four largest shareholders becomes more egalitarian, there is more control contestability and so greater firm values.

Two complementary measures of control contestability are the Shapley value and the high contestability dummy. The Shapley value is the solution concept for coalitional games. In this case, it will measure the probability that individual blockholders (or groups of shareholders) form part of a winning coalition. Calculation of Shapley values is somewhat problematic since most shareholders' stakes are unknown, but since they are often very low, we can assume they do not affect main voting coalitions. Prior to estimating this Shapley value for the main blockholder in a coalition of four agents, we rescaled the sum of the four largest shareholders to $100 \%$. If the largest blockholder held more than $50 \%$ of the votes, the Shapley value was set equal to 1 ; that is, the voting power of the largest stakeholder is treated as a winning coalition able to exert full control. If this blockholder could not hold a majority of voting, then its contestability power increased with lower Shapley values. The relationship between the Shapley value of the largest blockholder and firm performance should also be negative.

Maury and Pajuste (2005) suggest a dummy variable they call "high contestability dummy". It takes a value of 1 if the three largest blockholders cannot form a majority and the fourth largest holds at least $10 \%$ of the votes. The rationale is to capture cases where the first three main shareholders' power can be contested. One should expect firm performance to be better as contestability among the four largest shareholder increases. Hence, the relation is expected to be positive.

In contrast, many studies (Durnev \& Kim, 2005; Claessens, Djankov, Fan, \& Lang, 2002, and Claessens, Djankov, Fan, \& Lang, 2006) have stressed that higher separation between voting rights and control rights in the hands of the main blockholders may be associated with lower firm valuation and worse accounting performance since a negative entrenchment effect of extracting private rents can overcome the positive effects of blockholders' aligned incentives to run firms properly. We employ the largest shareholder's stake of direct ownership, CR1, and the sum of the direct ownership of the top four largest blockholders, CR4, to measure the incentive effect, and use a wedge variable proxied by the inverse of equity to voting ratio of CR1 and CR4 to account for the entrenchment effect.

Other control variables used in the regression equations include firm size, financial leverage, sales growth and asset tangibility. Firm size is measured either by the natural logarithm of total assets ( $\log$ assets) or by the natural logarithm of operating income $(\log O I) .{ }^{18}$ As in most studies, we expect a negative relationship between size and the performance measures since size also proxies for firm age and older firms have less dynamism. Leverage is proxied by two measures. The first is the ratio of book value of long-term liabilities to book value of total assets (leverage). The second is the book value of total liabilities divided by total assets (debt ratio). There is no established expected relation of these variables with firm valuation or performance since the empirical evidence suggests that leverage can have either a positive disciplinary device over management's free use of cash flow or a negative effect if it increases the probability of bankruptcy.

To measure investment opportunities, we use past growth in sales, measured by a moving average of the two and three previous real annual percentage growths in operating income ( growth2 and growth3). It is expected that firms with better growth opportunities have faster growth rates, so sales growth should be positively related to the valuation and performance measures. The

18 Original value series are at 1998 prices. 
last variable is asset tangibility, equal to plant, property and equipment valuation relative to the total assets ratio. Lower asset tangibility is a signal that a firm's cash flows are presumably generated by intangibles (know-how, branding) and hence implies high firm market value. The expected correlation is negative. Last, all regressions are controlled by industry dummies, SIC, to account for differences in asset structure, market competition, and other idiosyncratic aspects that may affect firm valuation, ownership or corporate governance. ${ }^{19}$ Regressions also include year dummies to account for time effects.

\subsection{Descriptive statistics}

Table 5 is a summary of statistics for the contestability, performance and firm characteristic variables. The maximum number of firm-years observations is 1092, corresponding to 233 firms with at least one voting-block. Tobin's $Q$ was quite low, with an average of 1.05 and a median of 0.79 . However, there was clearly some variation year by year since Tobin's $Q$ reached a maximum of 1.42 in 1998 and a minimum of 0.75 in 2002. The performance variables ROA and ROE also exhibit low levels. The medians are 2.5 and $4.3 \%$, respectively. Control contestability variables by turn show an increasing trend. The mean (median) of the Herfindal index based on equity differentials for the top four stakes is 0.14 (0.04). Moreover, this number was 0.19 in 2004 . The Shapley value averaged 0.71 and was increasing, which is relatively high compared to the 0.6 reported by Maury and Pajuste for Finnish firms, although their value stemmed from a three-player game instead of the four in our case. Thus, the numbers suggest that the higher the probability that the largest shareholder will form a coalition, the higher the contestability power of the next largest blockholders.

\subsection{Regression results}

We now consider the relationship between firm-level contestability and firm performance. Our hypotheses first test the relationship between control contestability and valuation measures and then test that between ownership and control rights. The econometric specification follows a general two-way error component model with a matrix dimension of $i \times t$ :

$$
Y_{i t}=B_{0}+B_{k} \mathbf{C}_{i t}+\varphi_{k} \mathbf{X}_{i t}+\mathrm{IND}_{j}+\left(\alpha_{i}+\lambda_{t}+\varepsilon_{i t}\right)
$$

where $Y_{i t}$ is the valuation/performance variable, such as Tobin's Q, MTSR, MTBR, ROA and ROE; $\mathbf{C}$ is the vector with the contestability variables and $\mathbf{X}$ is the vector with the standard controls above mentioned. The estimation of Eq. (9) is also controlled by industry and time dummies.

Bloch and Hege (2001) and Bolton and Von-Thadden (1998) found that large blockholders value liquidity in stocks, that the more liquid a stock is, the higher its transparency and the informational accuracy conveyed to investors, which could better its valuation. An important feature of the Colombian stock exchange has been the lack of actual offers of stocks and the low trading volume (the float) in the last 20 years. The delisting pattern shown in Table 2 reflects this corporate governance problem. Statistically, what one finds is that only a small fraction of firms trade their stocks, and from this small subset, a fraction of them had median or high trading volumes. Hence, the Colombian stock market is not liquid and taking the whole sample of firm-year observations for which Tobin's Q can be estimated can be misleading.

\footnotetext{
19 We classify industries with the two-digit United Nations Standard Industry Classification.
} 
Table 5

Summary of statistics_-valuation, contestability and performance variables

\begin{tabular}{|c|c|c|c|c|c|c|}
\hline \multirow[t]{2}{*}{ Variable } & \multicolumn{6}{|l|}{ Panel A } \\
\hline & Observed & Mean & Std. & Min & $\operatorname{Max}$ & P50 \\
\hline \multicolumn{7}{|l|}{ Value and performance } \\
\hline TOBIN'Q & 689 & 1.0593 & 1.4549 & 0.071 & 15.772 & 0.7906 \\
\hline Return on assests & 1074 & -0.0093 & 0.6064 & -18.555 & 0.910 & 0.0257 \\
\hline Return on Equity & 1074 & -0.0554 & 1.1095 & -28.619 & 1.638 & 0.0434 \\
\hline Market-to-book ratio & 689 & 2.4253 & 27.6810 & -0.187 & 711.817 & 0.6691 \\
\hline Market-to-sale ratio & 678 & 18.1232 & 180.3946 & 0.003 & 4376.831 & 0.9274 \\
\hline \multicolumn{7}{|l|}{ Control contestability } \\
\hline Herfindal index_concentration & 1092 & 0.2612 & 0.2311 & 0.0112 & 1.0000 & 0.1997 \\
\hline Herfindal index_differences & 1092 & 0.1415 & 0.2203 & 0.0000 & 1.0000 & 0.0404 \\
\hline High contestability dummy & 1092 & 0.1703 & 0.3761 & 0.000 & 1.000 & 0.0000 \\
\hline Shapley value & 1092 & 0.7086 & 0.2852 & 0.250 & 1.000 & 0.5000 \\
\hline \multicolumn{7}{|l|}{ Firm characteristics } \\
\hline Log-operating income & 1046 & 10.4724 & 2.1596 & -1.292 & 15.350 & 10.9047 \\
\hline Log-assets & 1074 & 11.3774 & 1.8174 & 4.556 & 16.276 & 11.5088 \\
\hline Asset tangibility & 1074 & 0.2060 & 0.1936 & 0.000 & 0.915 & 0.1609 \\
\hline Debt ratio & 1074 & 0.4001 & 0.5825 & 0.000 & 12.367 & 0.3445 \\
\hline Leverage & 1074 & 0.1621 & 0.4780 & 0.000 & 12.367 & 0.0848 \\
\hline Growth-sales (T-3) & 708 & 0.2155 & 1.3046 & -0.871 & 19.174 & 0.0363 \\
\hline \multirow[t]{2}{*}{ Mean } & \multicolumn{6}{|l|}{ Panel B } \\
\hline & 1996 & 1998 & 1999 & 2000 & 2002 & 2004 \\
\hline TOBIN'SQ & 1.1457 & 1.4211 & 1.1387 & 1.1024 & 0.7547 & 0.8639 \\
\hline Return on Equity & -0.0082 & -0.2375 & -0.2611 & 0.0508 & 0.0393 & 0.0970 \\
\hline Market to Book Ratio & 1.8328 & 9.1806 & 1.3184 & 0.8306 & 0.7050 & 0.8043 \\
\hline Herfindal Index_concentration & 0.2176 & 0.2489 & 0.2255 & 0.2537 & 0.3108 & 0.3153 \\
\hline Herfindal Index_differences & 0.1036 & 0.1288 & 0.1038 & 0.1286 & 0.1902 & 0.1951 \\
\hline Shapley Value & 0.6985 & 0.6756 & 0.6833 & 0.6987 & 0.7516 & 0.7633 \\
\hline
\end{tabular}

See Section 5.1 for definitions of terms.

Source: Our own estimations based on an assembled dataset from SVAL National Equity Registry Forms, companies' financial statements and stock prices.

Assuming that liquidity really matters, we run Eq. (11) only for those firms with some share liquidity.

The estimating sample was divided in two. One includes all the firm-year observations that have at least one blockholder and stock classified as of at least median liquidity. We take the liquidity index calculated by the Financial Superintendence as our selection device. ${ }^{20}$ The second sample comprises all firm-years observations for which a firm's stock was classified as highly liquid.

\footnotetext{
${ }^{20}$ In fact, the contestability controls were not significant for the full sample regressions although they kept the expected sign. From 1992 to the present, the former Superintendence of Securities and today's Financial Superintendence ranks shares according to an index created for tax purposes. The index, known locally as the Indice de Bursatilidad Accionaria, is calculated by using data on the number of days that a given stock is traded, the daily volume and the monetary amount. The index ranges between 0 , the lower bound, and 10, the upper bound.
} 
Of course, the number of firm-year observations decreases as the liquidity threshold increases. Although it can be argued that there may be some sample selection bias, the liquidity index was created in 1991 and so is an exogenous factor that just selects a sample of firms for which control contestability really matters.

Table 6 depicts the value regressions controlling by contestability for the sample of firmyear observations according to share liquidity. Panel A reports the findings for those firm-year observations (148) with liquidity above the median threshold while panel B reports only those firm-year observations (69) ranked as high liquidity stocks. Regressions in (1)-(3) for both cases depict the effect of control contestability on firm value. Hypothesis 1 is strongly validated since contestability variables exhibit the expected sign and regression coefficients are statistically significant at the 5\% level. The differences in the Herfindal index and the Shapley value of the largest block are robust variables. As long as there exists a more equal distribution of control rights among the four largest blockholders, investors assign a better valuation since none of the main blockholders can individually exploit its control rights to extract rents. Thus, the numbers suggest that if the differences in the Herfindal indices fall by $10 \%$, Tobin's Q rises on average between 0.37 and $0.68 \%$. The Shapley value for the largest shareholder is a proxy for the probability that the largest blockholder forms a coalition to exert firm control. If the main blockholder lacks enough control rights to hold a majority, the contestability increases as the voting rights of the second, third and fourth largest blockholders increase. In particular, if the probability of forming a coalition (Shapley value) decreases by $10 \%$, firm value rises between 2.7 and $3.8 \% .^{21}$

The last column in both panels reports the effect of direct ownership and control rights on firm valuation. Regression Eq. (4) presents the results only for the joint effect of the four largest shareholders (CR4). Clearly, when one uses a sample of firm-year observations that includes only firms whose stocks are liquid, the positive incentive effect regarding direct control and monitoring exerted by the top four shareholders tends to disappear. Contestability implies a conflict of interest among main investors if stock liquidity is relevant to investors' wealth. This control power is value-enhanced, in contrast to an absolute ownership concentration by a voting coalition that makes extracting rents to its own benefit easy. Further, the results also show that the entrenchment effect, given by the separation ratio of voting rights to equity, was insignificant. This outcome is a consequence of the low separation ratios where ultimate owners exert direct control on managers and thus minimize the agency problem of control delegation. Hence, Hypothesis 2 is no longer verified. Contestability turns out to be important among dominant investors when a firm's equity is liquid and tradable. ${ }^{22}$ Regression equations also show that the model explain about $50 \%$ of firm value.

Regarding standard controls, the results go in the same direction as reported in previous case studies, the debt to asset ratio and firm size for example. The former is associated with mature industries with low growth opportunities and the latter with the disciplinary role of leverage. In fact, leverage is used as a device to discipline incentives and retain control. ${ }^{23}$

\footnotetext{
21 Voting concentration was not significant at $10 \%$ but was close to that critical point (12\%). All regressions exhibited a negative sign.

${ }^{22}$ If the estimating sample includes all firms regardless of the liquidity of their shares, we get a direct and positive effect of ownership concentration on firm value. This result was first reported in Gutiérrez and Pombo (2007).

${ }^{23}$ For details, see, for example, Black et al. (2006) for Korea; see Claessens et al. (2002) for East Asian countries; De-Jong (2002) for Holland; and Gutiérrez and Pombo (2007) for Colombia.
} 
Table 6

Tobin's $Q$ and control contestability regressions by shares classified as median and high liquidity

\begin{tabular}{|c|c|c|c|c|c|c|c|c|}
\hline & \multicolumn{4}{|c|}{ Panel A: median liquidity } & \multicolumn{4}{|l|}{ Panel B: high liquidity } \\
\hline & (1) & (2) & (3) & (4) & $(5)$ & (6) & (7) & (8) \\
\hline $\begin{array}{l}\text { Log } \\
\text { HI_differences }\end{array}$ & $-0.0678(-2.5)^{* *}$ & & & & $-0.0368(-1.98)^{*}$ & & & \\
\hline $\begin{array}{l}\text { Log } \\
\text { HI_concentration }\end{array}$ & & $-0.0925(-1.63)$ & & & & $-0.0557(-1.64)$ & & \\
\hline $\begin{array}{l}\text { Shapley value } \\
1\end{array}$ & & & $-0.2736(-2.09)^{* *}$ & & & & $-0.3859(-2.85)^{* * * *}$ & \\
\hline $\mathrm{CR} 4$ & & & & $-0.2197(-0.93)$ & & & & $-0.2314(-1.18)$ \\
\hline $\begin{array}{l}\text { Votes } \\
\text { CR4/EquityCR4 }\end{array}$ & & & & $-0.0701(-0.60)$ & & & & $-0.0231(-0.23)$ \\
\hline Debtratio & $0.6708(4.62) * * *$ & $0.7234(5.18) * * *$ & $0.6694(4.56)^{* * *}$ & $0.7180(5.02) * * *$ & $0.5362(3.38)^{* * *}$ & $0.4887(3.36) * * *$ & $0.8297(3.53) * * *$ & $0.4989(3.30) * * *$ \\
\hline Growth (t-3) & $-0.1136(-1.31)$ & $-0.1267(-1.37)$ & $-0.1070(-1.26)$ & $-0.1120(-1.18)$ & $-0.0932(-1.20)$ & $-0.0960(-1.21)$ & $-0.1364(-1.71)^{*}$ & $-0.1003(-1.27)$ \\
\hline $\begin{array}{l}\text { Asset } \\
\text { tangibility }\end{array}$ & $-0.6511(-3.61)^{* * * *}$ & $-0.5574(-3.08)^{* * *}$ & $-0.5829(-3.65)^{* * *}$ & $-0.4908(-2.75)^{* * * *}$ & $-0.3035(-2.67)^{* * *}$ & $-0.2630(-2.34)^{* *}$ & $-0.5097(-3.80)^{* * *}$ & $-0.2299(-2.01)^{* *}$ \\
\hline Log-assets & $-0.2026(-4.04)^{* * * *}$ & $-0.1865(-3.73)^{* * * *}$ & $-0.1979(-3.76)^{* * *}$ & $-0.1825(-3.76)^{* * * *}$ & $-0.0393(-1.34)$ & $-0.0240(-0.85)$ & $-0.0638(-2.17) * *$ & $-0.0186(-0.73)$ \\
\hline Constant & $4.7885(5.73)^{* * *}$ & $4.6415(5.04)^{* * *}$ & $4.6570(5.5) * * *$ & $4.4343(4.66) * * *$ & $1.3014(2.99)^{* * * *}$ & $0.9002(2.26)^{* *}$ & $1.2231(3.07)^{* * *}$ & $0.8960(1.94)^{*}$ \\
\hline Observations & 148 & 148 & 148 & 148 & 69 & 69 & 69 & 69 \\
\hline$R$-squared & 0.533 & 0.504 & 0.503 & 0.489 & 0.496 & 0.476 & 0.566 & 0.471 \\
\hline
\end{tabular}

Notes: Variable definitions are in Appendix A1. All regressions include year dummies and industry dummies (not repored). Robust t-statistics are in parentheses; $\left(^{*}\right)$ significant at $10 \% ;(* *)$ significant at $5 \% ;(* * *)$ significant at $1 \%$.$$
\text { Souce: Or ownesimions bad a a }
$$ 


\subsection{Robustness tests}

A common point addressed by firm valuation regression is the issue of robustness and the endogeneity problem of ownership variables. Ownership affects firm value, but valuation has an impact on changes in ownership structure. To tackle this problem, we run instrumental-variable regressions. Table 7 depicts the two-stage least-squares regressions, which treat all contestability variables as endogenous variables. We use as instruments for those variables their own values lagged one period. Several comments are worth mentioning. First, all contestability variables keep the expected sign of negative relation and the size of the regression coefficients is similar. These effects are almost the same, in contrast to the original pooled OLS regressions. For instance, for the high liquidity sub-sample, a decrease of $10 \%$ on the HI-differences will raise firm value around $0.56 \%$, whereas this effect is $0.37 \%$ unless instrumental variables are performed. Second, standard controls exhibit the same sign and are still significant at 5\%. Hence, regressions that endogenize the proxies for control contestability confirm our first hypothesis; that is, firm value improves as control contestability increases.

Another robustness issue is how results differ from alternative performance measures. Table 8 displays the core results of firm performance and contestability regressions. The estimations are based on the full sample of firm-year observations. Performance accounting variables in contrast to firm value might be less sensitive to stock liquidity but more prone to diversion. Tobin's Q may suffer from measurements problems, especially when applied to firms in emerging markets where there exists local market power and market prices might be not in equilibrium. In addition, there are three elements that the full sample captures through performance regressions. First, the full panel includes firms with minimum stock trading. There are several firms whose stocks are traded one or two times per year at most. Second, there are observations of delisted companies that are lost if one takes only Tobin's Q as the dependent variable. Third, the sample includes bond issuers, which again are lost in the valuation regressions.

The econometric estimations use several alternative variables but the findings are best summarized by the market-to-sales (MTSR) and return-on-equity (ROE) ratios. The first important feature is that contestability results hold in these regressions. For all cases, contestability variables are statistically significant at the $10 \%$ level and have the expected sign for the MTSR and two of four cases for ROE regressions. A $10 \%$ reduction in the HI-differences will boost MTSR by $17 \%$. Further, if ownership concentration or the Shapley value decreases by 10\%, MTSR increases 31 and $91 \%$, respectively. If the cash flow rights of the top four shareholders decrease by $10 \%$, MTSR rises by $135 \%$-regression Eq. (4). Regarding the ROE results, only the Shapley value and the high contestability dummy (HCD) variables were statistically significant at $10 \%$. Again, if the probability of a winning coalition's pursuing absolute control drops by $10 \%$, the ROE ratio will rise by $0.9 \%$. The last equation in the regressions shows that the HCD reduces firm performance since the sign was negative instead of positive, which is the expected association. Recall that this dummy captures the control contestability held by the fourth largest shareholder over the top three voting blocks that cannot form a coalition with a simple majority. This implies that when the marginal voting block becomes a strategic player in a coalitional game, there is more control over cash flow extraction and tunneling made possible by other holding firms' operative leverage or investment capital.

The negative sign on ROE suggests that this fourth contestant has the opposite result in terms of limiting tunneling. Perhaps, this shareholder generates more conflicts within boards, making 
Table 7

Tobin's $Q$ and control contestability for shares classified as median and high liquidity (two-stage least-squares regressions)

\begin{tabular}{|c|c|c|c|c|c|c|}
\hline & \multicolumn{3}{|c|}{ Panel A: median liquidity } & \multicolumn{3}{|c|}{ Panel B: high liquidity } \\
\hline & (1) & (2) & (3) & (1) & (2) & (3) \\
\hline Log HI_differences & $-0.064(-2.36)^{* *}$ & & & $-0.056(-2.69)^{* * *}$ & & \\
\hline Log HI_concentration & & $-0.071(-1.16)$ & & & $-0.056(-1.5)$ & \\
\hline Shapley value 1 & & & $-0.282(-1.71)^{*}$ & & & $-0.571(-3.04)^{* * *}$ \\
\hline Debt_ratio & $0.672(4.72) * * *$ & $0.715(4.99) * * *$ & $0.669(4.7)^{* * *}$ & $0.630(3.78)^{* * *}$ & $0.489(3.16)^{* * *}$ & $1.056(4.03)^{* * *}$ \\
\hline Growth (t-3) & $-0.113(-1.31)$ & $-0.122(-1.33)$ & $-0.107(-1.26)$ & $-0.099(-1.29)$ & $-0.096(-1.20)$ & $-0.163(-1.99)^{*}$ \\
\hline Asset tangibility & $-0.640(-3.84)^{* * * *}$ & $-0.530(-2.96) * * *$ & $-0.587(-4.14) * * *$ & $-0.311(-2.68)^{* * *}$ & $-0.263(-2.36)^{* *}$ & $-0.615(-4.34)^{* * * *}$ \\
\hline Log-Assets & $-0.202(-4.15) * * *$ & $-0.186(-3.69)^{* * *}$ & $-0.198(-4.04)^{* * *}$ & $-0.041(-1.44)$ & $-0.024(-0.87)$ & $-0.077(-2.88)^{* * *}$ \\
\hline Constant & $4.826(5.96)^{* * *}$ & $4.527(5.00)^{* * *}$ & $4.672(6.40)^{* * *}$ & $0.729(2.14)^{* *}$ & $1.217(2.83)^{* * *}$ & $1.351(3.72)^{* * *}$ \\
\hline Observations & 148 & 148 & 148 & 69 & 69 & 69 \\
\hline$R$-squared & 0.533 & 0.503 & 0.503 & 0.484 & 0.476 & 0.540 \\
\hline
\end{tabular}

Notes: Variable definitions are in Appendix A1. All regressions include year dummies and industry dummies (not reported). Robust t-statistics are in parentheses; $(*)$ significant at $10 \% ;(* *)$ significant at $5 \% ;(* * *)$ significant at $1 \%$.

Source: Our own estimations based on a assembled dataset from SVAL companies' financial statements, RNVIs, and stock prices. 
Table 8

Firm performance and contestability: MTSR and ROE regressions

\begin{tabular}{|c|c|c|c|c|c|c|c|c|}
\hline & \multicolumn{4}{|c|}{ Market-to-sales ratio } & \multicolumn{4}{|l|}{ Return on Equity } \\
\hline & (1) & (2) & (3) & (4) & (1) & (2) & (3) & (4) \\
\hline Log HI_differences & $-1.692(2.37)^{* *}$ & & & & $-0.013-0.990$ & & & \\
\hline Log HI_concentration & & $-3.139(2.10)^{* *}$ & & & & $-0.030-0.860$ & & \\
\hline Shapley value 1 & & & $-9.166(1.95) *$ & & & & $-0.087(1.89)^{*}$ & \\
\hline High contestability dummy & & & & & & & & $-0.105(1.96)^{*}$ \\
\hline CR4 & & & & $-13.593(1.72)^{*}$ & & & & \\
\hline Votes CFW Equity CR4 & & & & $-1.599(-0.44)$ & & & & \\
\hline Debt ratio & $-2.006(-1.44)$ & $-2.009(-1.51)$ & $-2.003(-1.40)$ & $-2.176(-1.55)$ & $0.026(-1.3)$ & $0.027(-1.29)$ & $0.026(-1.30)$ & $0.023(-1.21)$ \\
\hline Growth (T-2) & $(3.66)^{* * *}$ & $12.377(3.67)^{* * *}$ & $12.467(3.70)^{* * *}$ & $12.416(3.68)^{* * *}$ & & & & \\
\hline Growth (T-3) & & & & & $-0.006(-0.81)$ & $-0.005(-0.77)$ & $-0.006(-0.92)$ & $-0.006(-0.97)$ \\
\hline Asset tangibility & $-2.492(-0.54)$ & $-0.847(-0.20)$ & $-1.796(-0.42)$ & $0.191(-0.04)$ & $-0.061(-0.98)$ & $-0.057(-0.89)$ & $-0.062(-0.96)$ & $-0.056(-0.86)$ \\
\hline Log-assets & $-3.998(2.54)^{* *}$ & $-3.958(2.54)^{* *}$ & $-3.945(2.53)^{* *}$ & $-4.154(2.41)^{* *}$ & $0.019(1.90)^{*}$ & $0.020(1.89)^{*}$ & $0.019(1.90)^{*}$ & $0.019(1.83)^{*}$ \\
\hline Constant & $41.477(2.43)^{* *}$ & $48.335(2.49)^{* *}$ & $45.252(2.47)^{* *}$ & $52.307(2.44)^{* *}$ & $-0.762(1.67)^{*}$ & $-0.701(-1.56)$ & $-0.670(-1.48)$ & $-0.705(-1.56)$ \\
\hline Observations & 554 & 554 & 554 & 554 & 696 & 696 & 696 & 696 \\
\hline$R$-squared & 0.27 & 0.27 & 0.27 & 0.27 & 0.12 & 0.12 & 0.12 & 0.12 \\
\hline
\end{tabular}

Notes: Variable definitions are in Appendix A1. All regressions include year dummies and industry dummies (not reported). Robust t-statistics are in parentheses; $(*)$ significant at $10 \% ;(* *)$ significant at $5 \% ;(* * *)$ significant at $1 \%$.

Source: Our own estimations based on a assembled dataset from SVAL companies' financial statements, RNVIs, and stock prices. 
decisions more costly, which might have a negative impact on firm performance. ${ }^{24}$ Lastly, wedge variables were dropped from the final estimations since they were not robust regressors in all cases. Therefore, the separation of ownership and control does not affect firm performance because of the direct monitoring that main shareholders exert on companies' management. Thus, the private control bias eliminates managers' entrenchment effect but raises new concerns regarding small shareholders' protection and the risk of expropriation. ${ }^{25}$

\section{Conclusions}

Control contestability has been shown to be important in previous studies that relate it to firm value. In this work, we test the effect of multiple large shareholders on firm value for a sample of about 233 non-financial Colombian firms during the period 1996-2004. The results corroborate our main hypothesis. More contestability of the largest blockholder's control helps limit tunneling and private extraction of rents. In other words, voting power distribution is a market or governance mechanism that is equally effective regardless of the relative development of the stock markets. This is partly because control has become more equally distributed among the largest blockholders, so there are fewer opportunities for bad corporate governance. In addition, the low separation between large shareholders' cash flow rights and voting rights implies direct monitoring of firm managers, which eliminates the moral hazard problem typically observed in widely held corporations.

In sum, the entrenchment and tunneling effects are limited as a consequence of the low separation ratios that allow ultimate owners to exert direct control on managers, minimizing the agency problem of control delegation through control contestability among the larger shareholders. This study provides more evidence for understanding the link between a firm's control and its performance in emerging countries where the civil law environment is associated with poor investor protection in the sense of La Porta et al. (2002). In many ways, our findings are in accordance with the theoretical predictions of Bloch and Hege (2001), who assert that, regardless of the degree of legal protection, the existence of multiple large shareholders can enhance a firm's performance. The policy implications are straightforward for capital market regulation. Instruments that help to democratize equity capital, or levy personal taxes on blockholder dividends that surpass some threshold lower than an absolute majority, or set a mandatory ruling about independent board members, or promote minorities' representation on boards will all increase control contestability and better firm governance.

\section{Acknowledgements}

We appreciate the comments of an anonymous referee and the Journal's editors, Robert Taggart and Kenneth Kopecky. We also thank the participants at the research seminar of the School of Management, Universidad de los Andes; the CEDE seminar of the Economics Department, Universidad de los Andes; the 2007 LACEA Congress held in Bogotá at Universidad de los Andes, and the participants at the IV Colombian Finance Symposium held at Universidad Tecnológica, Cartagena, Colombia. We also thank Roberto Fortich for his research assistance. Any remaining errors are our own.

\footnotetext{
${ }^{24}$ In most regressions HCD was not significant, but the regression coefficient exhibited a negative sign in all cases.

25 The regression results of contestability variables on firm performance also hold for the sub-sample of medium and high stock liquidity, which are not reported for space reasons.
} 


\section{Appendix A. Variable definitions in regression equations}

\begin{tabular}{|c|c|c|}
\hline Variable & Definition & Source \\
\hline Tobin's Q & $\begin{array}{l}\text { The ratio between market value end book value of assets. } \\
\text { Colombian accounting and tax regulations require that all } \\
\text { firms update their book values yearly, so the use of book } \\
\text { value of assets must be very close to replacement costs. } \\
\text { Market value of assets was estimated as the sum of I book } \\
\text { value of debt plus book value of preferred stocks and market } \\
\text { value of common stock. In turn, the yearly market value of } \\
\text { common stocks was calculated as the product of the average } \\
\text { market price times the number of common stocks }\end{array}$ & FS and BVC \\
\hline Return on assets ROA & The ratio of net profits after tax to total assets & FS \\
\hline Return on equity ROE & The ratio of net profits after tax to equity & FS \\
\hline MTSR & Market value of common stock divided by sales & FS \\
\hline MTBR & $\begin{array}{l}\text { The ratio between market value of common stock (as } \\
\text { defined above) and book value of common stock; the latter } \\
\text { is estimated as the sum of the book value of assets minus } \\
\text { the book value of liabilities and preferred stock }\end{array}$ & FS \\
\hline Votes $1-4$ & $\begin{array}{l}\text { The fraction of the votes held by the first (second, third and } \\
\text { fourth) largest shareholder }\end{array}$ & FS \\
\hline Equity $1-4$ & $\begin{array}{l}\text { The fraction of cash-flow rights held by the first (second, } \\
\text { third, and fourth) largest shareholder, respectively }\end{array}$ & FS \\
\hline Voting CR1/Equity CR1 & $\begin{array}{l}\text { The voting rights divided by equity rights of the first largest } \\
\text { shareholder }\end{array}$ & FS \\
\hline Voting CR4/Equity CR4 & $\begin{array}{l}\text { The sum of the voting rights divided by equity rights of the } \\
\text { first four largest shareholders }\end{array}$ & \\
\hline HI_concentration & $\begin{array}{l}\text { The sum of the squares of the four largest voting stakes, } \\
{\left[(\text { Votes } 1)^{2}+(\text { Votes } 2)^{2}+(\text { Votes } 3)^{2}+(\text { Votes } 4)^{2}\right]}\end{array}$ & FS \\
\hline HI_differences & $\begin{array}{l}\text { The sum of the squares of the differences between the first } \\
\text { and second largest voting stakes, the second and the third } \\
\text { largest voting stakes and the third and fourth largest voting } \\
\text { stakes, [Votes } 1-\text { Votes } 2]^{2}+[\text { Votes } 2-\text { Votes } 3]^{2}+[\text { Votes } \\
3 \text {-Votes } 4]^{2}\end{array}$ & FS \\
\hline Shapley value 1 & $\begin{array}{l}\text { The Shapley value solution for the largest shareholders in a } \\
\text { four-voting game }\end{array}$ & FS \\
\hline Herfindal contestability dummy & $\begin{array}{l}\text { Dummy variable that equals } 1 \text { if the sum of the voting } \\
\text { power held by the three largest shareholders does not } \\
\text { exceed } 50 \% \text {, and there is at least one more blockholder with } \\
\text { at least } 10 \% \text { of the votes, and } 0 \text { otherwise }\end{array}$ & FS \\
\hline Debt_ratio & The ratio of total liabilities to total assets & FS \\
\hline Growth $(t-n)$ & $\begin{array}{l}\text { The moving average of the n-previous real annual } \\
\text { percentage growth in operating income }\end{array}$ & FS \\
\hline Asset tangibility & $\begin{array}{l}\text { Total property, plants and equipments divided by total } \\
\text { assets. }\end{array}$ & FS \\
\hline Log assets & $\begin{array}{l}\text { Natural logarithm of total assets, all in } 1999 \text { Colombian } \\
\text { pesos }\end{array}$ & FS \\
\hline
\end{tabular}

Notes: $\mathrm{FS}=$ financial superintendence; $\mathrm{BVC}=$ Bolsa Valores de Colombia (Colombia's stock exchange). 


\section{References}

Baldone, S., Brioschi, F., \& Paleari, S. (1997). Ownership measures among firms connected by cross-shareholdings and further analogy with input-output theory. Mimeo: Politecnico di Milano.

Barca, F., \& Becht, M. (2000). The Control of Corporate Europe. Oxford: Oxford University Press.

Barca, F., \& Becht, M. (2001). The Control of Corporate Europe. New York: Oxford University Press.

Barclay, M. J., \& Holderness, C. J. (1989). Private benefits from control of public corporations. Journal of Financial Economics, 25, 371-395.

Bebczuk, R. (2007). Corporate governance, ownership and dividend policies in Argentina. In A. Chong \& F. Lopez-deSilanes (Eds.), Investor protection and corporate governance: Firm level evidence across Latin America. Washington, DC: The World Bank-Stanford University Press.

Bennedsen, M., \& Wolfenzon, D. (2000). The balance of power in closely held corporations. Journal of Financial Economics, 58, 113-139.

Berle, A., \& Means, G. (1932). The modern corporation and private property. New York: McMillan.

Bianchi, M., Bianco, M., \& Enriques, L. (2001). Ownership, pyramidal groups and the separation between ownership and control in Italy. In F. Barca \& M. Becht (Eds.), The control of corporate Europe. New York: Oxford University Press.

Black, B. S., Jang, H., \& Kim, W. (2006). Does corporate governance predict firms' market values? Evidence from Korea. Journal of Law, Economics, and Organization, 22, 366-413.

Bloch, F., \& Hege, U. (2001). "Multiple Shareholders and Control Contest” Mimeo, HEC School of Management Paris, March.

Bolton, P., \& Von-Thadden, E. L. (1998). Blocks, liquidity, and corporate control. The Journal of Finance, 53, 1-25.

Burkart, M. D., Gromb, D., \& Panunzi, F. (1997). Large shareholders, monitoring, and the value of the firm. Quarterly Journal of Economics, 112, 693-728.

Burkart, M. D., Gromb, D., \& Panunzi, F. (1998). Why higher takeover premia protect minority shareholders. Journal of Political Economics, 106, 172-204.

Chong, A., \& Lopez-de-Silanes, F. (Eds.). (2007). Investor Protection and Corporate Governance: Firm Level Evidence across Latin America. Washington DC: The World Bank, Inter-American Development Bank, Stanford University Press.

Claessens, S., Djankov, S., \& Lang, L. (2000). The separation of ownership and control in East Asian Corporations. Journal of Financial Economics, 58, 81-112.

Claessens, S., Djankov, S., Fan, J., \& Lang, L. (2002). Disentangling the incentive and entrenchment effects of large shareholdings. Journal of Finance, 57, 2741-2771.

Claessens, S., Djankov, S., Fan, J., \& Lang, L. (2006). The benefits and costs of group affiliation: Evidence from East Asia. Emerging Markets Review, 7, 1-26.

Demsetz, H., \& Lehn, K. (1985). The structure of corporate ownership: Causes and consequences. Journal of Political Economy, 93, 1155-1177.

Durnev, A., \& Kim, E. H. (2005). To steal or not to steal: Firm attributes, legal environment, and valuation. The Journal of Finance, 60, 1461-1493.

Faccio, M., \& Lang, L. (2002). The ultimate ownership of western european corporations. Journal of Financial Economics, $65,365-395$.

Gomes, A., \& Novaes, W. (2006). Sharing of control versus Monitoring as Corporate Governance Mechanisms. Mimeo, Washington University, May.

Gutiérrez, L. H., \& Pombo, C. (2007). Corporate governance and firm valuation in colombia. In A. Chong \& F. Lopez-deSilanes (Eds.), Investor protection and corporate governance: Firm level evidence across Latin America. Washington, DC: The World Bank-Stanford University Press.

Gutiérrez, L. H., Pombo, C., \& Taborda, R. (2008). Corporate ownership and control in Colombian corporations. Quarterly Review of Economics and Finance, 48, 22-47.

Gutiérrez, M., \& Tribó, J. A. (2004). Private Benefits Extraction in Closely-Held Corporations: The case for Multiple Large Shareholders. ECGI Finance Working Paper No 53.

Harris, M., \& Raviv, A. (1988). Corporate governance: Voting rights and majority rules. Journal of Financial Economics, 20, 203-235.

Hart, O. (1995). Firms, contracts and financial structure. London: Oxford University Press.

Holderness, C. G. (2006). A Contrarian View of Ownership Concentration in the United States and Around the World. Mimeo, Boston College, September.

Jensen, M. C., \& Meckling, M. (1976). Theory of the firm: Managerial behavior, agency costs and ownership structure. Journal of Financial Economics, 31, 3-24. 
Johnson, S., La Porta, R., Lopez-de-Silanes, F., \& Shleifer, A. (2000). Tunneling. American Economic Review, 90, $22-27$. La Porta, R., Lopez-de-Silanes, F., Shleifer, A., \& Vishny, R. (1998). Law and finance. Journal of Political Economy, 106, 1113-1155.

La Porta, R., Lopez-de-Silanes, F., \& Shleifer, A. (1999). Corporate ownership around the world. The Journal of Finance, $54,471-517$.

La Porta, R., Lopez-de-Silanes, F., Shleifer, A., \& Vishny, R. (2002). Investor protection and corporate valuation. The Journal of Finance, 57, 1147-1170.

Leal, R., \& Carvalhal-da-Silva, A. (2007). Corporate Governance and Value in Brazil. In A. Chong \& F. Lopez-de-Silanes (Eds.), Investor protection and corporate governance: Firm level evidence across Latin America. Washington, DC: The World Bank-Stanford University Press.

Leffort, F., \& Walker, E. (2007). Corporate governance, market valuation and payout policy in Chile. In A. Chong \& F. Lopez-de-Silanes (Eds.), Investor protection and corporate governance: Firm Level evidence across Latin America. Washington, DC: The World Bank-Stanford University Press.

Maury, B., \& Pajuste, A. (2005). Multiple large shareholders and firm value. Journal of Banking and Finance, 29, $1813-1834$.

Pagano, M., \& Roell, A. (1998). The choice of stock ownership structure: Agency costs, monitoring, and the decision to go public. Quarterly Journal of Economics, 113, 187-225.

Sharpe, W. F. (1964). Capital asset prices: A theory of market equilibrium under conditions of risk. Journal of Finance, $19,425-442$.

Shleifer, A., \& Vishny, R. (1986). Large shareholders and corporate control. Journal of Political Economy, 94, 461-488. 